\title{
PALAVRAS DE AGRADECIMENTO
}

\author{
Henrique Cl. de Lima Vaz SJ (CES-BH)
}

Peço inicialmente que essas breves palavras não sejam interpretadas apenas como cumprimento do rito sagrado do agradecimento, mas, e sobretudo, como expressão de um sentimento profundo, feito da modéstia e orgulho, que nasceu em mim desde o momento em que me vi fazendo parte de uma das maiores e mais importantes universidades da América Latina.

O honrosíssimo título de Professor Emérito restitui-me ao seio da Universidade da qual a aposentadoria afastara-me. É, pois, natural que aquele antigo sentimento renasça com novo vigor e leve-me a dizer algo sobre os 22 anos nos quais tive o privilégio de ensinar na nossa Alma Mater.

Peço, pois, licença para recordar brevemente alguns dos passos que me levaram um dia, nos idos de 1964, a atravessar, como Professor, as portas da UFMG.

Confesso que a perspectiva de vir a ensinar numa grande Universidade pública não fazia parte do meu projeto de vida. Estávamos então nos inícios da década de 60. Eu era Professor na nossa modesta Faculdade da Filosofia, que está completando 60 anos, e tinha sua sede no Colégio Anchieta de Nova Friburgo, RJ. Meu programa de vida era o de dedicar-me, num ambiente ideal e propício ao trabalho intelectual, ao estudo, à pesquisa e ao ensino.

Como alguns ainda se lembram, nos começos dos anos de 1964 pesadas nuvens acumulavam-se no céu da política brasileira e logo sobre todos nós abateu-se o vendaval autoritário. Fui obrigado, cercado de suspeitas, a deixar Nova Friburgo. E para onde dirigir-me senão para as minhas Minas Gerais e para essa amável cidade de Belo Horizonte onde vivera os anos felizes da adolescência? Como jesuíta coloquei-me à disposição dos meus superiores que, porém, deixaram campo livre às minhas opções. Foi então que um bondoso destino ou uma bondosa Providência trouxe-me até à UFMG pelas mãos 
de dois ínclitos Mestres: o Prof. Arthur Versiani Velloso e o Prof. Aluízio Pimenta. O saudoso e inesquecível Prof. Velloso convidou-me a dar aulas de História da Filosofia no Departamento de Filosofia da hoje FAFICH, da qual era Diretor. E o Prof. Aluízio Pimenta, recém nomeado Reitor da Universidade convocou-me para com ele colaborar na Reitoria, sobretudo no estudo dos temas da Reforma Universitária, então na ordem do dia.

Atravessei assim os umbrais da Universidade na qual deveria permanecer por 22 anos. Mas devo dizer que não entrava numa casa estranha e, para mim, desconhecida. Ao ser acolhido na UFMG senti-me sob o teto de uma morada familiar, onde podia respirar um ar de família, Aqui meu venerando Pai, Prof. Teodoro da Fonseca Vaz, foi catedrático de Geologia e Mineralogia na Escola de Engenharia, da década de 20 a 1950. Meu tio. Alcindo da Silva Vieira, também da Escola de Engenharia, foi Reitor da Universidade na década de 40. Aqui estudaram e se formaram meus irmãos e meus primos. Como não respirar entre as paredes da UFMG o ar revigorante e estimulante de uma grande família unida pelo comum amor do saber?

Os anos passados no Departamento de Filosofia marcaram profundamente minha vida e deram-lhe uma nova densidade intelectual e humana. Aqui vivi a experiência intelectual decisiva de ver aberto diante do meu espírito um horizonte muito mais vasto de idéias, de interrogações, de problemas do que aquele que limitava meu universo filosófico até então, construído segundo os paradigmas da filosofia clássica na sua versão tomista. Devo dizer, no entanto, que essa experiência intelectual não provocou em mim nenhuma atitude iconoclasta de "desconstrução", mas permitiu que, partindo do sólido terreno do pensamento clássico, pudesse avançar pelos múltiplos e entrecruzados caminhos da grande filosofia moderna. Permitiu, sobretudo, esse extraordinário encontro com o pensamento hegeliano e que foi, provavelmente, o mais importante desafio teórico encontrado ao longo da minha trajetória filosófica.

Mas no Departamento de Filosofia foi-me dado viver igualmente urna profunda experiência humana. Também aqui o conteúdo da experiência exprimiu-se na dilatação das fronteiras do universo humano no qual até então habitara, o universo da comunidade religiosa de cuja riqueza muito recebi, mas que era, naqueles tempos pre-conciliares encerrado entre lindes bem definidas. O mundo universitário é como o microcosmos da sociedade civil, na sua complexidade, no seu dinamismo, nos seus problemas e desafios. Aí encontrei um espaço humano onde era possível viver formas, para mim inéditas, deste ato fundamental de uma experiência de vida em comum que é o ato do encontro do outro. Ora, o Departamento de Filosofia foi, para mim, o espaço privilegiado no qual pude viver alguns desses encontros, dos quais 
minha sensibilidade logrou alcançar uma percepção mais fina da misteriosa realidade do outro, minha inteligência uma compreensão mais rica do paradigma do alter ego, minha liberdade um apelo mais insistente para realizar-se na convivialidade entre diferenças por vezes tão assinaladas.

Ao falar de experiência humana na vida universitária que creio ter vivido intensamente, como não evocar os grandes amigos e excelentes colegas que já nos deixaram? E como fazê-lo sem correr o risco de omissões imperdoáveis? Seja-me permitido ao menos, nesse momento, uma recordação afetuosa daqueles com os quais experimentava uma afinidade mais profunda. O grande Mestre Velloso, figura tutelar e patrono da FAFICH, espírito paradoxal na sua superabundante riqueza humana e intelectual que sabia unir um amável ceticismo, um vigoroso eros filosófico, um senso inato da ordem que alimentava sua admiração tantas vezes manifestada pela Companhia de Jesus. Sílvio Barata Viana, o helenista rigoroso, o professor de admirável consciência da dignidade e seriedade do magistério, que, naqueles tempos madrugadores, desde as 6,30 estava já na sala de aula escrevendo no quadro-negro com sua bela caligrafia os textos gregos que iria explicar em classe. Flávio Neves, psiquiatra e psicólogo atraído pela Filosofia, humanista erudito, poliglota consagrado, incomparável contador de histórias naquelas saudosas manhãs do $8^{\circ}$ andar no prédio da rua Carangola. Padre Orlando de Oliveira Vilela, mestre que iniciou tantas gerações no estudo da Filosofia, tomista de espírito aberto e generoso, brilhante escritor, grande amigo. Finalmente a mais suave e a mais melancólica das recordações, a da nossa querida Sônia Maria Viegas. Sem dúvida uma das mais brilhantes inteligências que o nosso Departamento conheceu, inequívoca vocação filosófica, rica de muitos dons humanos e intelectuais. Tive o privilégio de tê-la como aluna logo que aqui cheguei. Apenas saída da adolescência, já seu cintilante espírito manifestava-se na insaciável curiosidade intelectual, nas interrogações apaixonadas sobre os mais difíceis problemas filosóficos, na fascinação pela Grécia que a acompanharia na sua breve e fulgurante carreira. À memória de Sônia quero trazer, nesse momento, a recordação comovida de uma grande amizade e de uma admiração que permanece intacta, indiferente aos anos que passam. Falei de alguns que já nos deixaram. Falar dos que nos alegram com sua presença, seria um nunca acabar. Desejo, porém, deixar aqui uma palavra de agradecida recordação ao corpo de funcionários da antiga FAFICH, tão eficiente e tão amigo. $\mathrm{Na}$ impossibilidade de todos nomear, representando a todos e todas sejam lembradas D. Zuleika e D. Téa na Secretaria e D. Sebastiana na manutenção.

Querida Diretora Vera Alice: em suas mãos generosas e amigas deposito todos os agradecimentos que seria impossível enumerar nesse momento. Mas não posso deixar de agradecer em particular os membros da egrégia Congre- 
gação da FAFICH que por unanimidade concederam-me o precioso título de Professor Emérito. Da UFMG que conheci há quase 40 anos minha memória guarda a imagem altiva e nobre de uma Instituição que bem poderia espelharse na sentença latina: temporibus iniquis aequa sanctaque mansit (Em tempos de iniquidade permaneceu igual a si mesma fiel à sua identidade). Honra e orgulho de Minas Gerais e do Brasil tal é a Universidade na qual novamente entro com o coração cheio de jubilo e alegria!

Obrigado! 